\title{
CONTROL OF COMPOSITE NONLINEAR DEFORMATION BY LOCAL CURVATURE OF YARNS
}

\author{
S.B. Sapozhnikov, A.V. Kheruvimov, A.S. Khoruzhiy \\ South Ural State University, Chelyabinsk, Russian Federation \\ E-mail: sapozhnikovsb@susu.ru
}

Using the refined theory of dry bundles, we analyzed the curvature (length diversity) of yarns in the fabric composite for obtaining the maximum effect of pseudo-ductility (constant yield stresses during the deformation). Because of length diversity, yarns destruction happens consequently, starting with the straight yarns and ending with the most curved ones. The polymer matrix ensures a monolithic structure and high damping of the oscillations due to the intensification of matrix shears during tension/compression of the composite. To simulate an ideal elastoplastic stress-strain diagram of the composite, we formulated the law of changes in fiber lengths, the mechanical properties of which were considered to be the same. To study the technological possibilities of the local curvatures of yarns in fabric preforms, we performed experiments using the indenting method and arrays of conical and flat needles. We showed that conical needles allow us to obtain simultaneous curvature of warp and weft yarns to the same extent. The needle spacing controls the ratio of straight and curved yarns; so, by changing the spacing we can bring this ratio closer to the value required for getting the needed length of the yield plateau. In the case of flat needles with various orientation to the warp yarns, we can obtain anisotropic yarns curvature (of only one yarns family, for example). For experimental deformation of the fabrics with locally curved yarns we used aramid fabrics of plain weave and carbon fabrics of twill weave.

Keywords: fabric composite; pseudo-ductility; curvature of yarns; dry bundles theory; indentation.

Introduction. Modern fiber polymer composites gain increasing popularity in the construction of critical structures for the aerospace industry due to their high strength and stiffness $[1,2]$. However, their mechanical characteristics also include brittleness (small possible deformations) and simultaneous failure $[3,4]$, which decrease the operational reliability of constructions with stress concentration zones (for example, open holes and roundings) and small safety factors. Therefore, substantial nonlinear deformation, pseudo-ductility, together with the retained high strength and stiffness, is highly desirable in composites. Due to the growth of possible technical applications pseudo-ductility of composites has been drawing rising attention of researchers last 5-7 years, which can be seen from the number surge of relevant SCOPUS papers (Fig. 1).

Nowadays researches on pseudo-ductility are connected with hybrid composites, which contain both stiff and compliant fibers [5, 6]. Because of stiff fibers (carbon) composites have a high elastic modulus, and compliant fibers (glass, aramid) support stiff ones during the deformation process [7, 8], creating conditions for their kinematic loading and gradual failure. The certain ratio of stiff and compliant fibers results in a yield plateau on the stress-strain diagram $[9,10]$. The length of this plateau depends on the distribution of the stiff fibers strength: longer plateau corresponds to wider distribution [7].

Therefore, the yield plateau length adjustment is limited and depends on the fibers production technology. Moreover, as fabric yarns consist of hundreds and thousands of elementary fibers, the distribution of the yarn's strength is insignificant. To avoid these restrictions, we proposed a modification method for UD strips and materials of flat weave (e.g., fabric, twill). This method is based on the regular local bending of yarns, which creates the preset length diversity of yarns. Hence, there is no need to combine stiff and compliant yarns: curved and straight yarns in the same layer will be compliant and stiff, respectively. Polymer treatment creates the composite layer with pseudo-plastic properties, which depend only on the length diversity of yarns. Furthermore, shear strains in affected areas of this layer intensify the damping of oscillations. 


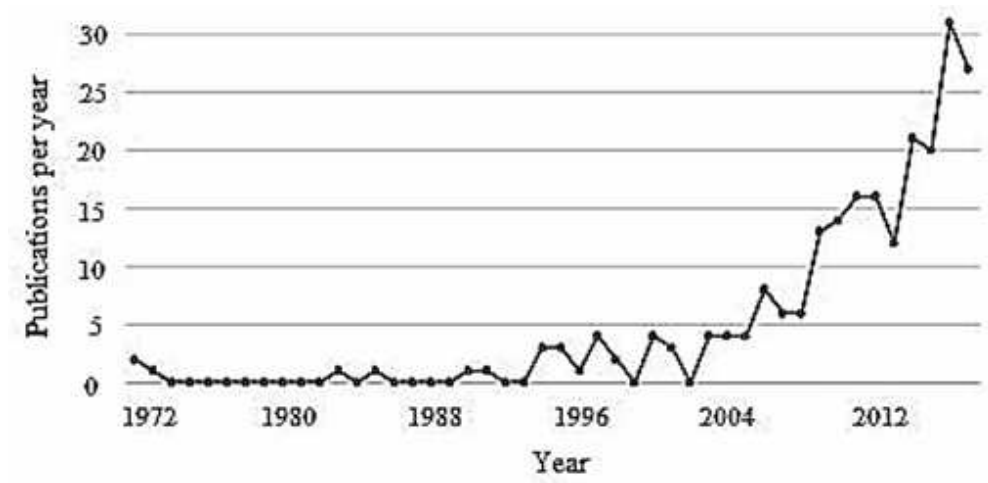

Fig. 1. Number of SCOPUS publications on topic pseudo ductility composites per year (1972-2017)

Model. Consider the tension of a flat UD layer with locally curved yarns of different lengths (Fig. 2, a). Yarns have the same mechanical properties: elastic modulus $E$, ultimate stress $X$, linear postcritical behavior up to ultimate failure, which is characterized by softening modulus $E^{\prime}$. This model of UD composite behavior at the kinematic loading (Fig. 2, $b$, solid line) was proposed in [11]. For curved yarns the stress-strain curve has the same shape but is shifted by the value of specific elongation $\delta$ (Fig. $2, b$, dashed line). To model the functioning of the ideal elastic-plastic material (Fig. 2,c) with the defined yield strength $\sigma_{\mathrm{T}}$ and the yield plateau of the maximal length $\varepsilon_{b}$ at tension it is necessary to obtain the length function (the dependence of yarn's specific elongation on the yarn's number).

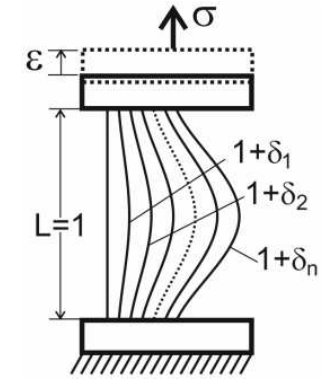

$a$

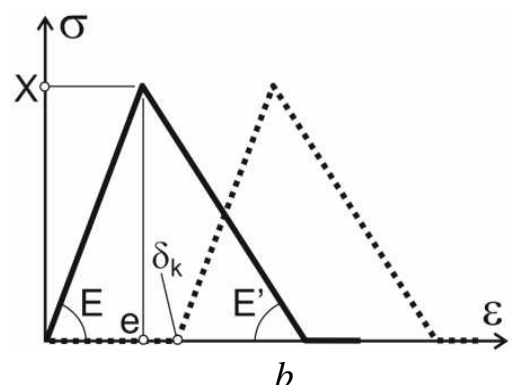

Fig. 2. Properties of curved yarns

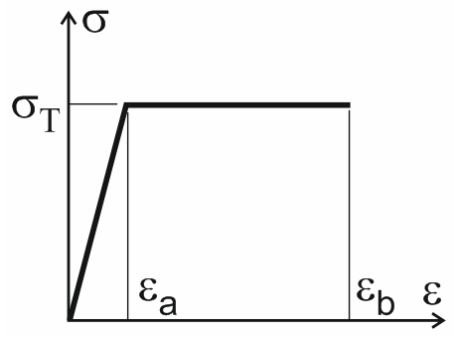

$c$

For simplicity, we assume that the composite has $N$ yarns or groups of yarns of different lengths. Piecewise linear dependence of the stress $s$ on the deformation $\varepsilon$ of $i$-th yarn with the arbitrary curvature $\delta_{i}$ can be formulated as follows:

$$
s\left(\varepsilon, \delta_{i}\right)=\left\{\begin{array}{l}
0,0<\varepsilon<\delta_{i} ; \\
E\left(\varepsilon-\delta_{i}\right), \delta_{i}<\varepsilon<\delta_{i}+\frac{X}{E} ; \\
X-E^{\prime}\left(\varepsilon-\delta_{i}-\frac{X}{E}\right), \delta_{i}+\frac{X}{E}<\varepsilon<\delta_{i}+\frac{X}{E}+\frac{X}{E^{\prime}} ; \\
0, \varepsilon>\delta_{i}+\frac{X}{E}+\frac{X}{E^{\prime}} .
\end{array}\right.
$$

Superposition of stresses (1) for the case of the parallel connection of yarns with different $\delta_{i}$ is written as follows:

$$
\sigma(\varepsilon)=\frac{1}{N} \sum_{i=1}^{N} s\left(\varepsilon, \delta_{i}\right)
$$

We calculated stress-strain diagrams of yarns with the defined curvatures by using the superposition method, implemented in MathCAD package.

Calculation example. In linear approximation length function $\delta_{i}=i \cdot d$, where $d$ is the elongation step, and $i$ is yarn's number. For modeling of yarns made of carbon fibers (with the volume ratio $\sim 60 \%$ ) in the epoxy matrix [12] we used the following mechanical parameters: $E=150 \mathrm{GPa}, X=1500 \mathrm{MPa}$ и $E^{\prime}=300 \mathrm{GPa}$. Fig. 3 presents the diagram of kinematic loading of one yarn and yarns bundle with the 
fixed elongation step $d=0,2 \%$. This value of the elongation step corresponds to the yield strength oscillations less than $5 \%$, which can be neglected in engineering applications.
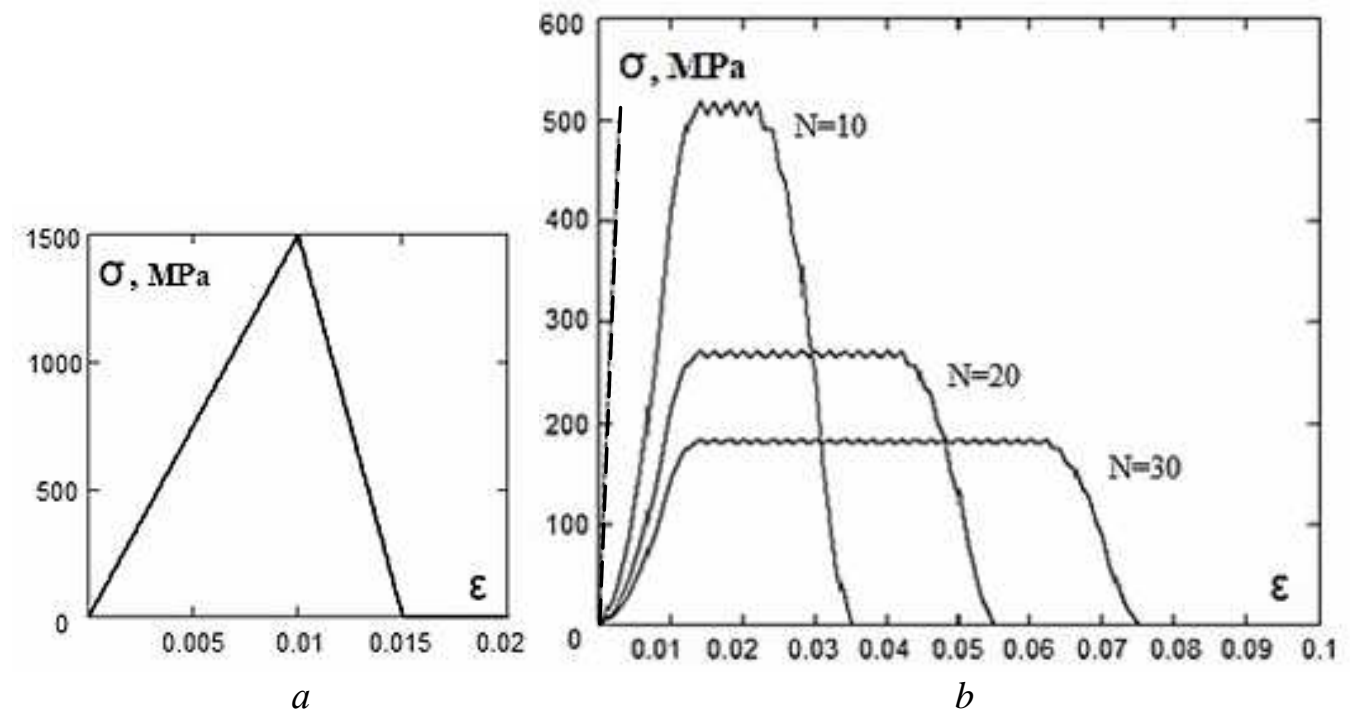

Fig. 3. Diagrams of kinematic loading of (a) one yarn and (b) 10, 20, and 30 yarns of different length

Fig. 3, $b$ shows that the composite's yield plateau is longer for yarns with a wider length range. However, at the same time yield strength decreases, and specific energy of deformation (area under the stress-strain curve) remains the same and equal to $\sim 11,3 \mathrm{MPa}$, which coincides with the fracture energy of one yarn at the kinematic loading.

We calculated the elastic range of the stress-strain curve, using dry bundles approximation. Therefore, we neglected the bending stiffness and yarn's shift in the epoxy matrix. In real cases, slightly curved yarns will have a higher elastic modulus, while straightening [13]. Moreover, in the initial section of the stress-strain curve, the composite will have bigger stiffness than the simulated predictions (see dashed line in Fig. 3, $b$ ).

Experimental tests. To validate our models, we experimentally investigated aramid fabrics of plain weave (P110) [14], modified by indenting.

Firstly, we used cylindrical needles of diameter $2 \mathrm{~mm}$ with a sharp conical end. Fig. $4, b$ shows that the fabric area, affected by a needle, is limited to the square $5 \times 5 \mathrm{~mm}^{2}$. Outside this area the fabric is not deformed. So, if the indenting step is larger than $5 \mathrm{~mm}$, there will be straight yarns in the fabric. The width of P110 fabric yarns equals to $0,5 \mathrm{~mm}$. Therefore, if the indenting step equals to $5 \mathrm{~mm}$, in repeated affected areas of the fabric we will have almost symmetrical arrays of curved yarns of different lengths ( 5 to the left and 5 to the right from the needle hit). These lengths for Fig. 4, $b$ are: 5,00, 5,10, $5,22,5,37$, and 5,60 $\mathrm{mm}$ (left array); 5,45, 5,35, 5,20, 5,15, and 5,00 $\mathrm{mm}$ (right array). Of course, in practice, an indenter will hit arbitrary places, so the curvatures and lengths of yarns will vary.

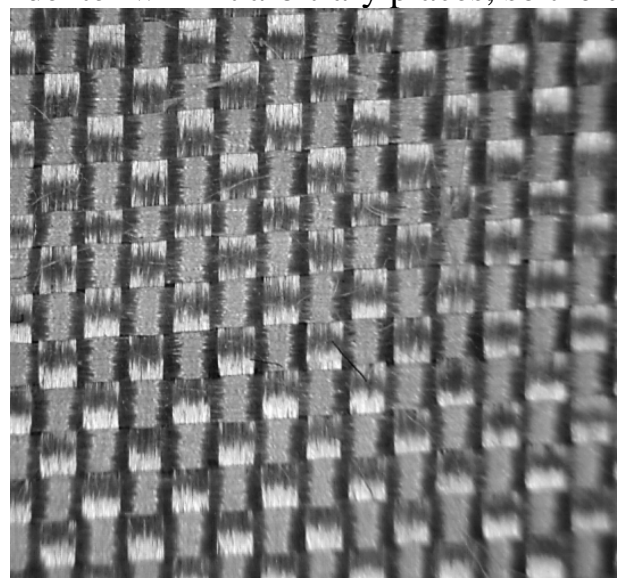

$a$

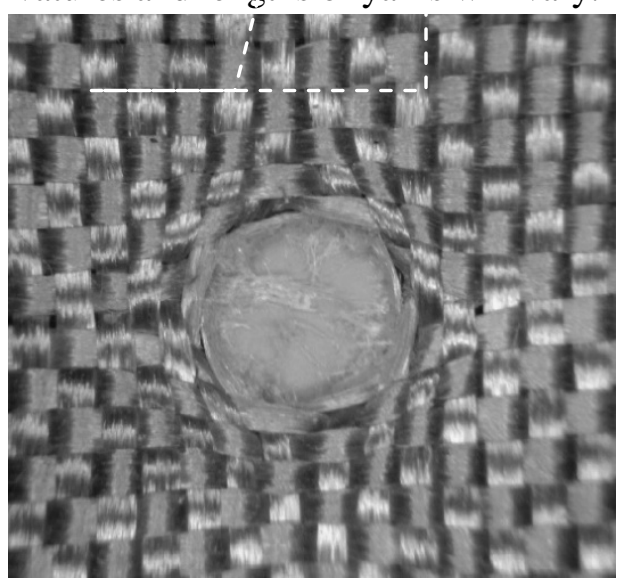

6

Fig. 4. Aramid fabric of plain weave P110: a) before indenting; $b$ ) after indenting by conical needle 


\section{Механика}

For the sample, depicted in Fig. 4, $b$ (single hit), we calculated the stress-strain curve (see Fig. 5), using mechanical properties of aramid yarn RUSAR [14]: linear density $\sim 28$ tex, $E=70 \mathrm{GPa}, X=2000$ $\mathrm{MPa}, E^{\prime}=100 \mathrm{GPa}$. The dashed line in Fig. 5 stands for the yield strength $\sim 400 \mathrm{MPa}$ of the sample with the periodic indenting through the whole fabric area (indenting step $5 \mathrm{~mm}$ ). As both warp and weft yarns are curved, mechanical properties during tension along these yarns will be the same (isotropic modification of fabric).

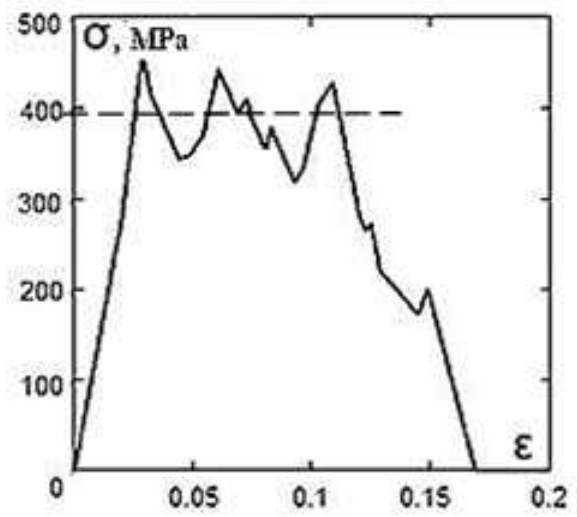

Fig. 5. Stress-strain diagram of the sample, depicted in Fig. 5, $b$

Secondly, we used flat needles of width, equal to $3 \mathrm{~mm}$, and thickness, equal to $1 \mathrm{~mm}$ (Fig. 6, $a$ ). In this case, periodic indenting (direction of hits is $45^{\circ}$ to horizontal/vertical lines, shown by white arrows on Fig. 6) led to the anisotropic curvature: only warp (vertical) yarns were curved, weft yarn remained straight (Fig. 6, b). Fig. 6, $c$ presents the fabric of twill weave modified by indenting by conical needle oriented at $45^{\circ}$ to horizontal/vertical lines. Because of high lateral yarn's stiffness the area, affected by the flat needle or the conical indenter of a diameter of $3 \mathrm{~mm}$, has quite big linear dimension: $100 \mathrm{~mm}$. White ellipses are the needle orientation schemes.

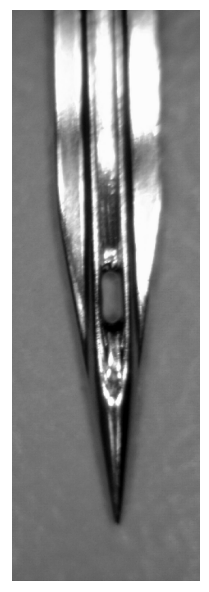

$a$

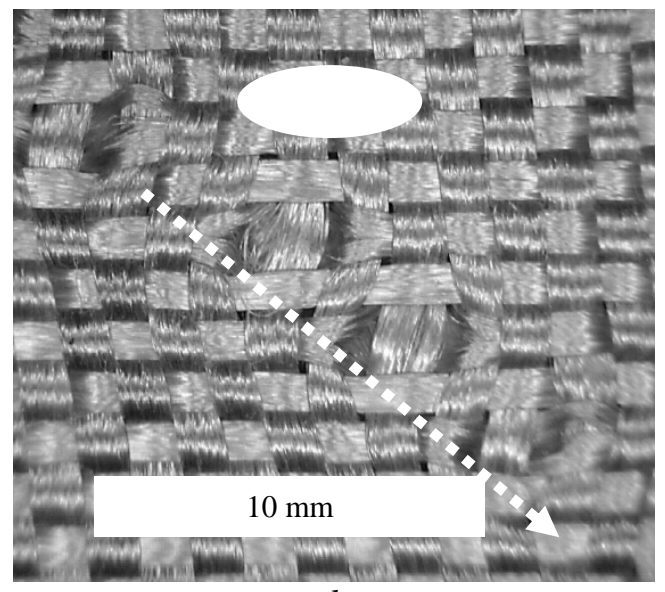

$b$

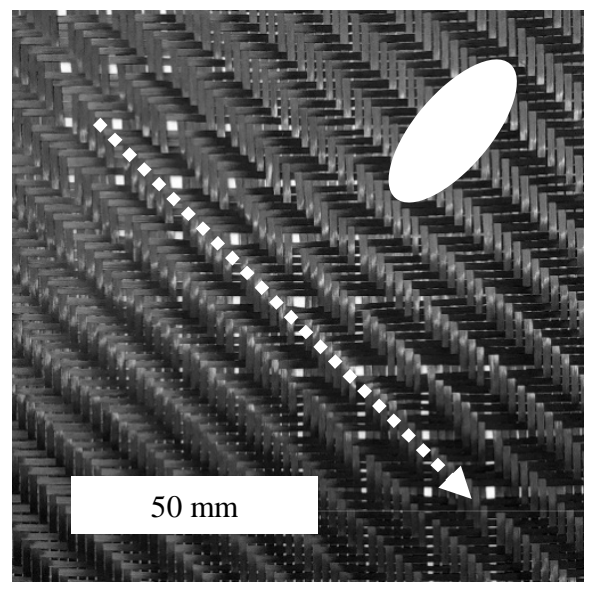

Fig. 6. Flat needle (a) and fabrics of $b$ ) plain and $c$ ) twill weave after indenting by flat and conical needle, respectively

Conclusions. Modeling showed the great potential of the method of local curvature of yarns, consisted of brittle fibers, for achieving a long yield plateau of a composite Failure of high-quality carbon fibers happens at relative deformations of around $1 \%$. By introducing length diversity of yarns (with the elongation step of $0,2 \%$ ) we achieved ultimate stress of approximately $300 \mathrm{MPa}$ and more than $500 \mathrm{MPa}$, and failure deformation more than $4 \%$ and $2 \%$ for the case of 20 and 10 different yarn's lengths, respectively.

Indenting by conical needles of a diameter of $2 \mathrm{~mm}$ with the indenting step of $5 \mathrm{~mm}$ along warp and weft yarns of aramid fabric of flap weave P110 resulted in the material with the yield strength of $400 \mathrm{MPa}$ and yield plateau of $10 \%$, which is unattainable for traditional fabric composites. These characteristics will allow us to use the indenting technology for the aerospace constructions with stress concentration zones (e.g. holes or roundings). Because of pseudo-ductility our technology will decrease 
stress concentrations and increase failure loading, the same effect as in hybrid composites [10, 15], where layers of fiberglass and carbon fibers alternate, or carbon and glass fibers are mingled in one yarn of a composite.

This work was financially supported by the Russian Science Foundation (project No. 18-19-00377).

\section{References}

1. Daniel I.M., Ishai O. Engineering mechanics of composite materials. Oxford university press, 2006, 432 p.

2. Gibson R.F. Principles of composite materials mechanics. CRC Press, 2007, 579 p.

3. Kaddour A.S., Hinton M.J., Li S., Smith P.A. Damage prediction in polymeric composites: Update of Part (A) of the Third World-Wide Failure Exercise (WWFE-III). Transactions of 18th International Conference on Composite Materials, South Korea, QinetiQ Ltd, 2011, 5 p. Available at: http://www.iccm-central.org/Proceedings/ICCM18proceedings/data/2.\%20Oral\%20Presentation/Aug23 (Tuesday)/T45\%20Mechanical\%20and\%20Physical\%20Properties/T45-5-IF1621.pdf, accessed 12.12.2018

4. Yan S., Zeng X., Long A. Experimental assessment of the mechanical behaviour of 3D woven composite T-joints. Composites part B: Engineering, 2018, Vol. 154, pp. 108-113. DOI: 10.1016/j.compositesb.2018.08.007

5. Kretsis G. A review of the tensile, compressive, flexural and shear properties of hybrid fibre reinforced plastics. Composites, 1987, Vol. 18, Issue 1, pp. 13-23. DOI: 10.1016/0010-4361(87)90003-6

6. Manders P.W., Bader M.G. The strength of hybrid glass/carbon fibre composites. Part 1. Failure strain enhancement and failure mode. Journal of Material Science, 1981, Vol. 16, Issue 8, pp. 22332245. DOI: $10.1007 / \mathrm{BF} 00542386$

7. Swolfs Y., Gorbatikh L., Verpoest I. Fibre hybridisation in polymer composites: a review. Composites part A: Applied Science and Manufacturing, 2014, Vol. 67, pp. 181-200. DOI: $10.1016 /$ j.compositesa.2014.08.027

8. Sapozhnikov S.B. Defekty i prochnost' armirovannykh plastikov (Defects and strength of reinforced plastics), Chelyabinsk, Izdatel'stvo Chelyabinskogo gosudarstvennogo tekhnicheskogo universiteta Publ., 1994, 161 p. (in Russ.).

9. Fuller J., Wisnom M.R. Damage suppression in thin ply angle-ply carbon/epoxy laminates. Transactions of 19th International Conference on Composite Materials (ICCM19), Montreal, July, 2013, 8 p.

10. Czél G., Wisnom M.R. Demonstration of pseudo-ductility in high performance glass/epoxy composites by hybridisation with thin-ply carbon prepreg. Composites part A: Applied Science and Manufacturing, 2013, Vol. 52, pp. 23-30. DOI: 10.1016/j.compositesa.2013.04.006

11. Sandhu R.S. Nonlinear response of unidirectional and angle-ply laminates. 15th Structural Dynamics and Materials Conference, Las Vegas, NV, U.S.A., 1974. DOI: 10.2514/6.1974-380

12. Barbero E.J. Introduction to Composite Materials Design. Boca Raton: CRC Press, 2018, 525 p. http://barbero.cadec-online.com/icmd, accessed 24.01.2019

13. Skudra A.M., Bulavs F.Ya. Prochnost' armirovannykh plastikov (Strength of reinforced plastics). Moscow, Khimiya Publ., 1982, 213 p. (in Russ.).

14. http://www.aramid.ru/ru, accessed 12.12.2018

15. Yu H.N., Longana M.L., Jalalvand M., Wisnom M.R., Potter K.D. Pseudoductility in intermingled carbon/glass hybrid composites with highly aligned discontinuous fibres. Composites part A: Applied Science and Manufacturing, 2015, Vol. 73, pp. 35-44. DOI: 10.1016/j.compositesa.2015.02.14 


\title{
УПРАВЛЕНИЕ НЕЛИНЕЙНОСТЬЮ ДЕФОРМИРОВАНИЯ КОМПОЗИТА С ПОМОЩЬЮ ЛОКАЛЬНОГО ИСКРИВЛЕНИЯ НИТЕЙ
}

\author{
С.Б. Сапожников, А.В. Херувимов, А.С. Хоружий \\ Южно-Уральский государственный университет, г. Челябинск, Российская Федерация \\ E-mail: sapozhnikovsb@susu.ru
}

На основе уточнённой теории сухих пучков выполнен анализ необходимой искривлённости («разнодлинности») нитей в тканевом композите для получения максимального эффекта псевдопластичности - постоянства напряжений «текучести» при деформировании. Разнодлинность обеспечивает последовательное разрушение нитей: сначала разрушаются прямолинейные нити, а в конце - максимально искривлённые. Наличие полимерной матрицы обеспечивает монолитность и высокое демпфирование колебаний за счёт интенсификации сдвигов в матрице при растяжении/сжатии композита. Для имитации идеальной упругопластической диаграммы растяжения композита был найден закон изменения длин волокон, механические свойства которых считались одинаковыми. Экспериментальные исследования технологических возможностей локального искривления нитей в тканевых преформах выполнены методом индентирования массивом конических или плоских игл. Показано, что при использовании конических игл реализуется синхронное искривление нитей основы и утка в равной степени. Изменяя шаг игл, можно программировать соотношение прямолинейных и искривлённых нитей так, чтобы оно максимально соответствовало расчётной величине, необходимой для получения заданной длины площадки «текучести». Применение плоских игл с различной ориентацией к направлению основных нитей позволяет получать «анизотропное» искривление нитей, например, искривление лишь одного семейства. Экспериментальные исследования деформирования тканей с локально искривлёнными нитями выполнены на арамидных тканях полотняного переплетения и тканях из углеродных волокон саржевого плетения.

Ключевые слова: тканевый композит; псевлопластичность; искривлённость нитей; теория сухого пучка; индентирование.

\section{Литература}

1. Daniel, I.M. Engineering mechanics of composite materials / I.M. Daniel, O. Ishai. - Oxford university press, 2006. $-432 \mathrm{p}$.

2. Gibson, R.F. Principles of composite materials mechanics / R.F. Gibson. - CRC Press, 2007. $579 \mathrm{p}$.

3. Kaddour, A.S. Damage prediction in polymeric composites: Up-date of Part (A) of the Third World-Wide Failure Exercise (WWFE-III) / A.S. Kaddour, M.J. Hinton, S. Li, P.A. Smith // Transactions of 18th International Conference on Composite Materials. - South Korea, QinetiQ Ltd, 2011. 5 p. Available at: http://www.iccm-central.org/Proceedings/ICCM18proceedings/data/2.\%20Oral\%20 Presentation/Aug23(Tuesday)/T45\%20Mechanical\%20and\%20Physical\%20Properties/T45-5-

IF1621.pdf, accessed 12.12.2018

4. Yan, S. Experimental assessment of the mechanical behaviour of 3D woven composite T-joints / S. Yan, X. Zeng, A. Long // Composites part B: Engineering. - 2018. - Vol. 154. - P. 108-113.

5. Kretsis, G. A review of the tensile, compressive, flexural and shear properties of hybrid fibre reinforced plastics / G. Kretzis // Composites. - 1987. - Vol. 18, Issue 1. - P. 13-23.

6. Manders, P.W. The strength of hybrid glass/carbon fibre composites. Part 1. Failure strain enhancement and failure mode / P.W. Manders, M.G. Bader // Journal of Material Science. - 1981. Vol. 16, Issue 8. - P. 2233-2245.

7. Swolfs, Y. Fibre hybridisation in polymer composites: a review / Y. Swolfs, L. Gorbatikh, I. Verpoest // Composites part A: Applied Science and Manufacturing. - 2014. - Vol. 67. - P. 181-200. 
8. Сапожников, С.Б. Дефекты и прочность армированных пластиков / С.Б. Сапожников. Челябинск: Издательство Челябинского государственного технического университета, 1994. $161 \mathrm{c}$.

9. Fuller, J. Damage suppression in thin ply angle-ply carbon/epoxy laminates / J. Fuller, M.R. Wisnom // Transactions of 19th International Conference on Composite Materials (ICCM19). Montreal, July 2013. -8 p.

10. Czél, G. Demonstration of pseudo-ductility in high performance glass/epoxy composites by hybridisation with thin-ply carbon prepreg / G. Czél, M.R. Wisnom // Composites part A: Applied Science and Manufacturing. - 2013. - Vol. 52. - P. 23-30.

11. Sandhu, R.S. Nonlinear response of unidirectional and angle-ply laminates / R.S. Sandhu // 15th Structural Dynamics and Materials Conference. - Las Vegas, NV, U.S.A., 1974.

12. Barbero, E.J. Introduction to Composite Materials Design / E.J. Barbero. - Boca Raton: CRC Press, 2018. $-525 \mathrm{p}$.

13. Скудра, А.М. Прочность армированных пластиков / А.М. Скудра, Ф.Я. Булавс. - М.: Химия, 1982. - 213 с.

14. http://www.aramid.ru/ru (дата обращения: 12.12.2018).

15. Pseudoductility in intermingled carbon/glass hybrid composites with highly aligned discontinuous fibres / H.N. Yu, M.L. Longana, M. Jalalvand et al. // Composites part A: Applied Science and Manufacturing. - 2015. - Vol. 73. - P. 35-44.

Поступила в редакцию 1 октября 20182 